\title{
PARA UMA SEMIOLOGIA PSICANALÍTICA DA PAIXÃO NA ANTIGUIDADE GREGA E SEUS SENTIDOS ADICTIVO E TÓXICO'
}

\section{Victor Eduardo Silva Bento}

Resumo: Trata-se de pesquisa de revisão de literatura. Seu objetivo foi realizar a semiologia psicanalítica da paixão na Antiguidade grega. Discutiu-se a hipótese central que compara "paixão" com "adicção" e "tóxico". Analisou-se: $1^{\circ}$ - Os sentidos e a origem etimológica da paixão em Aristóteles. Destacou-se aqui, em sentido amplo, "paixão como fato de sofrer passivamente uma ação" e, em sentido restrito, como "fato de sofrer passivamente uma ação dolorosa ou prejudicial"; $2^{\circ}$ - Os sentidos da paixão em Platão. Evidenciaram-se aqui, em sentido geral, "paixão-sensível como fato de se sofrer passivamente uma ação" e, em sentido particular, "paixão como cegueira da realidade", "como ilusão sensorial" e "como submissão a uma ação do mundo exterior sobre o corpo"; $3^{\circ}$ - O sentido paradoxal das paixões em Platão persistiria a partir da Renascença, especialmente em Descartes e em Freud?; e $4^{\circ}$ - Seria o "phármakon" platônico a origem semiológica dos sentidos "tóxico" e paradoxal das paixões em geral?

Palavras-chave: Paixão. Adicção. Tóxico. Antiguidade grega. Semiologia psicanalítica.

\section{Introdução}

Como seu título sugere, o objetivo deste trabalho é realizar a semiologia psicanalítica da paixão na Antiguidade grega discutindo a hipótese central que compara

1 Este artigo foi retirado da tese de doutorado em Psicopatologia Fundamental e Psicanálise, tese não publicada do autor intitulada:"La Passion Amoureuse 'Toxique': une Approche Psychanalytique à Partir de la Sémiologie et du Narcissisme chez Freud" (Bento, 1996). Por se tratar de tese realizada na Universidade Paris 7 , suas citações são todas em francês. Em função desta particularidade, decidiu-se dar o seguinte tratamento às citações desta tese retomadas neste trabalho: as citações das obras em francês foram traduzidas para o português pelo autor, quando não foi possível substituí-las por suas correspondentes traduções em edições em português das obras citadas. 
este termo com aqueles de adicção e tóxico. Por "semiologia" entende-se, juntamente com seu criador Saussure (1916/1995a, 1916/1995b), o estudo dos signos (termos) no seio da vida social (nos ritos, nos mitos, nos escritos clássicos etc.). Sobre os detalhes do método de pesquisa semiológico e, particularmente, sobre a "semiologia psicanalítica", ver Bento (1996, 2006b, 2007a, 2007b). E sobre outra ilustração da aplicação prática deste método semiológico no campo das toxicomanias, das adicções e das paixões tóxicas, além daquela que será objeto do presente artigo, ver Bento (2007c). Estando em questão os sentidos paixão na Antiguidade grega, abrir-se-á este artigo, no item seguinte, com a abordagem dos sentidos e da origem etimológica da paixão em Aristóteles.

\section{Os sentidos e a origem etimológica da paixão em Aristóteles}

Conforme já discutido em Bento (1996, 2006a), a origem etimológica do termo paixão é encontrada na Antiguidade grega, em Aristóteles, que distinguia "agir" de "sofrer" (tradução do verbo francês pâtir), no contexto genérico das formas ativas e passivas dos verbos."Sofrer" (pâtir), ou sua forma passiva, indicava que o sujeito sofria passivamente a ação expressada pelo verbo, como, por exemplo:"o bolo foi devorado pelos convidados."Devido a essa generalidade desse termo, existiam diversos tipos de paixão em Aristóteles (as quatorze paixões de Aristóteles). Existia, assim, entre os gregos, um pathos (paixão) em sentido amplo, que exprimia o fato de uma alma que sofria um movimento, o que era a expressão nela de uma impressão vinda do exterior. Em outras palavras, "paixão",em oposição à ação, significava passividades diversas diante do fato de se sofrer de uma maneira geral uma ação. A esse respeito, Lalande escreverá:

\section{PAIXÃO}

A. Sentido primitivo (... uma das dez categorias de ARISTÓTELES).

Sobre Paixão - Sentido A. O desaparecimento deste sentido será de lamentar? Seria necessário, na linguagem filosófica, relevar essa acepção ou criar um termo novo para a representar? Dizia-se na primeira redação deste artigo que a antiga oposição entre ação e paixão "representava um modo bastante superficial da descrição dos fatos, tirada sem dúvida por Aristóteles da distinção entre as formas ativas e passivas dos verbos" (TRENDELENBURG, De Aristotelis categoriis, p. 15), distinção à qual já não atribuímos importância lógica, e que não está de acordo com o ponto de vista da física moderna, em que as ações e reações são consideradas como recíprocas. J. Lachelier pensa, pelo contrário, que esta distinção era profunda e importante, e lembra o papel considerável que a oposição entre agir e sofrer desempenha na filosofia e principalmente na teoria 
do conhecimento, em Espinosa e Leibniz. [Ele] considera que seria bom não perder paixão no sentido antigo e etimológico. (Lalande, 1926/1996, p. 781)²

Este verbo em francês (pâtir), em sentido amplo, traduzido para o português como"sofrer",derivou do pathos da Antiguidade grega, também em sentido amplo. Pathos, no dicionário clássico de língua francesa do século XX, de nome Le petit Robert, é um termo oriundo do grego antigo. Significa sofrimento, paixão. Patho, derivado de pathos, significa, segundo o mesmo dicionário, afecção, doença (Robert, 1992, p. 1376). Portanto, em Aristóteles, pathos é sinônimo de "paixão", ambos os termos, em sentido amplo, significando um sofrimento passivo, também em sentido amplo. Deste "pathospaixão" genérico derivará um patho específico, sinônimo de "afecção", de "doença", significando aqui um sofrimento igualmente específico.

Sendo assim, ao lado desse sentido amplo do termo "paixão," encontra-se, também em Aristóteles, um sentido específico desse termo. Num sentido particular, subir (cuja tradução para o português é "sofrer") se transforma em souffrir (cuja tradução para o português também é "sofrer"). Mais precisamente, "paixão, em sentido amplo, como fato de sofrer (subir) passivamente uma ação", passa a ser "paixão, em sentido restrito, como fato de sofrer (souffrir) passivamente uma ação dolorosa ou prejudicial", isto é, "paixão-sofrimento". A este propósito, Aristóteles escreverá em Metafísica sobre esta "paixão-afecção", onde a palavra "pathos" aparece evocada pelo termo "afecção":

[Os significados de afecção]

(1) Afecção significa, num primeiro sentido, uma qualidade segundo a qual algo pode se alterar: por exemplo, o branco e o preto, o doce e o amargo, o peso e a leveza e todas as outras qualidades deste tipo.

(2) Noutro sentido, afecção significa a atuação dessas alterações, isto é, as alterações que estão em ato.

(3) Ademais, dizem-se afecções especialmente as alterações e as mudanças danosas e, sobretudo, os danos que produzem dor.

(4) Enfim, chamam-se afecções as grandes calamidades e as grandes dores. (Aristóteles, 2002, p. 247) ${ }^{3}$

Num sentido particular, a "paixão-afecção" se refere às "alterações e aos movimentos prejudiciais e sobretudo aos prejuízos desagradáveis" (Aristote, 1991, p. 208).Dommage (prejuízo), segundo Robert (1992), é"prejuízo sofrido por alguém" (p. 567). Nuisible (prejudicial), no mesmo dicionário, remete aos seguintes adjetivos sinônimos: "perigoso, desfavorável, penoso, funesto, daninho, nefasto, nocivo, tóxico".E Robert dá o exemplo de um "clima prejudicial à saúde" (p. 1288, itálicos e tradução nossos).

2 Ver passagem correspondente na edição francesa (Lalande, 1926/1993, p. 745).

3 Ver passagem correspondente na edição francesa (Aristote, 1991, p. 208). 
Por um lado, essas definições, particularmente as acepções de "tóxico" e "prejudicial à saúde", parecem evocar a hipótese central deste trabaIho (aquela que compara a paixão com o tóxico), bem como a semiologia psicanalítica do termo "toxicomania" (ver Bento, 1993, 1996, 1999, 2007c). Como se discutiu particularmente em Bento $(1996,1999)$, embora o uso de drogas remonte à Antiguidade, a noção de "toxicomania",tal como concebida atualmente, é moderna, surgindo no final do século XIX, no contexto da medicina, ligada aos sentidos de toxicomania como doença, como degenerescência, como amoralidade e como paixão. Se pode, então, questionar se, na origem etimológica do termo "paixão" em Aristóteles, não se encontra, especialmente nessas "afecções" (paixões, doenças) denominadas "as grandes calamidades e as grandes dores", o embrião deste moderno sentido de "toxicomania como paixão".

Por outro lado, esse sentido específico de "paixão como fato de sofrer passivamente uma ação prejudicial, dolorosa",em Aristóteles, pareceria também lembrar a etimologia do termo "tóxico."Como se discutiu em Bento $(1996,2006 a)$, no dicionário clássico de língua francesa do século XVIII, Diderot e D'Alembert definem toxicum da seguinte maneira:

Veneno que os Citas e alguns outros povos bárbaros esfregavam na ponta de suas flechas; o toulola dos Índios modernos é talvez o mesmo veneno; o que é certo, segundo o testemunho dos historiadores, é que a ferida tocada pelo toxicum dos Citas era mortal; de onde vem que se utilizou a mesma palavra na língua latina, para marcar um veneno contra o qual nada pode impedir o efeito. (Diderot \& D'Alembert, 1765/1967, p. 501, tradução nossa)

Esse sentido específico de "paixão como fato de sofrer passivamente uma ação prejudicial, dolorosa", em Aristóteles, não pareceria lembrar o "toxicum", isto é, um sofrimento passivo, prejudicial para alguém que é atacado por uma flecha envenenada?

Como se sabe, antes do surgimento do termo"paixão" em Aristóteles, os sentidos desse termo já eram abordados por Platão no contexto de sua teoria sobre o mundo sensível. Pretende-se, então, no item seguinte, discutir as questões acima levantadas e se aprofundar na análise das significações mais originárias desse termo, examinando as contribuições platônicas sobre os sentidos da paixão.

\section{Os sentidos da paixão em Platão}

Antes do surgimento do termo "paixão" com Aristóteles, a abordagem da paixão foi desenvolvida por Platão através de sua teoria sobre o sensível, como se existisse uma passionalidade encarnada nos interesses corporais do homem. O que se encontra, especialmente na"Alegoria da Ca- 
verna",apresentada por Platão em A República, é uma oposição entre o mundo sensivel (a paixão) e o mundo inteligível (o logos, a razão), uma concepção de "paixão como submissão à impressão (ação) do mundo exterior sobre o corpo", o que cegaria o homem, impedindo-o, assim, de aceder à realidade, ao saber, à verdade. O homem ordinário, sensível, apaixonado, é, em Platão, como um prisioneiro encerrado numa caverna de ilusões. Sobre isto, Platão escreverá:

- Em seguida - continuei -, imagina a nossa natureza, relativamente à educação ou à sua falta, de acordo com a seguinte experiência. Suponhamos uns homens numa habitação subterrânea em forma de caverna, com uma entrada aberta para a luz, que se estende a todo o comprimento dessa gruta. Estão lá dentro desde a infância, algemados de pernas e pescoços, de tal maneira que só lhes é dado permanecer no mesmo lugar e olhar em frente; são incapazes de voltar a cabeça, por causa dos grilhões; serve-lhes de iluminação um fogo que se queima ao longe, numa elevação, por detrás deles; entre a fogueira e os prisioneiros há um caminho ascendente, ao longo do qual se construiu um pequeno muro, no gênero dos tapumes (paredes de separação) que os homens dos "robertos" (dos marionetes) colocam diante do público, para mostrarem as suas habilidades por cima deles.

- Eu os vejo - disse ele.

- Veja também ao longo deste muro homens que transportam toda a espécie de objetos, que o ultrapassam: estatuetas de homens e de animais, de pedra e de madeira, de toda a espécie de lavor; como é natural, dos que os transportam, uns falam, outros seguem calados.

- Estranho quadro e estranhos prisioneiros são esses de que tu falas - observou ele.

- Semelhantes a nós - continuei. - Em primeiro lugar, pensas que, nestas condições, eles tenham visto, de si mesmo e dos outros, algo mais que as sombras projetadas pelo fogo na parede oposta da caverna?

- Como não - respondeu ele -, se são forçados a manter sempre a cabeça imóvel?

- E os objetos transportados? Não se passa o mesmo com eles?

- Sem dúvida.

- Então, se eles fossem capazes de conversar uns com os outros, não te parece que eles julgariam estar a nomear objetos reais, quando designavam o que viam?

- Realmente.

- E se a prisão tivesse também um eco na parede do fundo? Quando algum dos transeuntes falasse, não te parece que eles não julgariam outra coisa, senão que era a voz da sombra que passava?

- Por Zeus, que sim! 
- De qualquer modo - afirmei -, pessoas nessas condições não pensavam que a realidade fosse senão a sombra dos objetos.

- Exatamente - disse ele.

- Considera pois - continuei - o que aconteceria se eles fossem soltos das cadeias e curados da sua ignorância, para ver se, regressados à sua natureza, as coisas se passavam deste modo. Logo que alguém soltasse um deles, e o forçasse a endireitar-se de repente, a voltar o pescoço, a andar e a olhar para a luz, ao fazer tudo isso, sentiria dor, e o deslumbramento impedi-lo-ia de fixar os objetos cujas sombras via outrora. Que julgas tu que ele diria, se alguém lhe afirmasse que ate então ele só vira coisas vãs, ao passo que agora estava mais perto da realidade e via de verdade, voltado para objetos mais reais? E se ainda, mostrando-lhe cada um desses objetos que passavam, o forçassem com perguntas a dizer o que era? Não te parece que ele se veria em dificuldades e suporia que os objetos vistos outrora eram mais reais do que os que agora lhe mostravam?

- Sem dúvida - afirmou. (Platão, 2004, pp. 210-211)4

Algumas observações poderiam ser feitas sobre a passagem acima citada. Primeiramente, parece que se pode reencontrar aqui o mesmo sentido amplo de "paixão como fato de sofrer passivamente uma ação" tal como ele aparece em Aristóteles. Os prisioneiros da caverna de Platão, "algemados de pernas e pescoços, de tal maneira que só lhes é dado permanecer no mesmo lugar e olhar em frente", sofrem a ação da "iluminação [de] um fogo que se queima ao longe, numa elevação, por detrás deles." Dito de outra maneira, estando imobilizados, acorrentados, esses prisioneiros se submetem à ação do mundo exterior representado pela imagem do fogo situado numa posição de superioridade e de dominação em relação a eles - "numa elevação, por detrás deles". Dessa forma, eles só poderiam aceder às ilusões do mundo sensível, às "sombras projetadas pelo fogo na parede oposta da caverna"; "eles julgariam estar a nomear objetos reais, quando designavam o que viam": apenas sombras, na realidade!

Em segundo lugar, essa oposição que faz aqui Platão entre a sombra, de um lado, e a realidade, de outro, parece lembrar a oposição clássica em psicanálise entre libido narcísica e libido objetal (ver a discussão dessa oposição em Bento, 1994a, 1994b, 1995, 1996, 1998, 2003), assim como o Narciso do mito. Efetivamente, esse acede apenas à sua própria imagem refletida sobre a água, sem ali se reconhecer. A cegueira de Narciso, no que concerne à sua realidade própria e à realidade em geral, não poderia ser comparada àquela do prisioneiro da caverna de Platão? Aquilo que Narciso vê diante dele na superfície da água também não seria uma espécie de sombra, de reflexão luminosa? Em outras palavras, a percepção de Narciso não poderia ser considerada como um fenômeno comparável àquele das "sombras projetadas pelo fogo na parede oposta da caverna", fazendo face aos prisioneiros? 0 homem comum, sensível, apaixonado, de Platão, não seria ele um Narciso?

Ver passagem correspondente na edição francesa (Platon, 1966, pp. 273-274). 
Como terceira observação, pode-se comparar a noção platônica de "paixão,'implícita na sua teorização sobre o sensível na"Alegoria da Caverna", e a noção de "adicção". No Grand Dictionnaire de la Psychologie, Valleur (1991, p. 15) apresenta o termo "adicção" como sinônimo de "toxicomania" da seguinte maneira: substantivo inglês, relação de dependência alienante, particularmente farmacodependência, assuétude, ou toxicomania (itálico nosso). Sobre as origens do termo "adicção", Diderot e D'Alembert escrevem:

ADICÇÃO... na lei romana, é a ação de fazer passar ou de transferir bens a um outro, seja por sentença de uma corte, seja por via de venda àquele que oferece mais. Veja ALIENAÇÃO.

Ele [o termo adicção] é formado de addico, uma das palavras determinadas ao uso dos juízes romanos, quando eles permitiam a entrega da coisa ou da pessoa sobre a qual se havia passado um julgamento.

Eis porque os bens adjudicados desta maneira pelo pretor ao verdadeiro proprietário eram chamados bona addicta; e os devedores entregues por esta mesma via a seus credores para pagar suas dívidas se chamavam servi addicti.

Addictio in diem, significava a adjudicação de uma coisa a uma pessoa por um certo preço, até que um dia determinado o proprietário ou alguma outra pessoa desse ou oferecesse mais. (Diderot \& D'Alembert, 1751/1988, p. 128, tradução nossa)

Como se vê acima, "adicção" remete aos tempos da República Romana e aos sentidos de "adicção como escravização por determinação legal como última forma de pagamento de dívidas, como servidão, como submissão a alguma dominação etc.".Tal acepção não se parece com essa noção platônica de "paixão-sensível" associada à idéia de aprisionamento numa caverna, de submissão à ação do mundo exterior sobre o corpo? Não se poderia extrair de Platão, implicitamente sugerido na "Alegoria da caverna", um sentido de "paixão como escravização-adicção"?

Como quarta observação sobre a "Alegoria da Caverna" de Platão, pode-se começar por sublinhar a concepção platônica de "paixão-sensível como cegueira, ignorância do real, em nome de uma vida 'fantasmática"'. Na versão francesa da passagem de Platão (1966) acima citada, esse autor escreve: "O que crês tu então que ele [o homem comum, semelhante a um prisioneiro desta caverna] responderá se alguém lhe vem dizer que ele só viu até então vãos fantasmas, mas que no presente, mais perto da realidade e voltado para objetos mais reais, ele vê mais precisamente?" (p. 274, tradução e itálicos nossos). Uma das acepções da palavra fantôme (fantasma) que apresenta Robert (1992, p.759), no dicionário clássico de língua francesa do século XX, remete ao termo fantasmagorie (fantasmagoria). Fantasme (fantasma), por sua vez, remete, no mesmo dicionário, à acepção que possuía o termo fantôme no século XIV e ao sentido tão difundido no século XX em psicanálise: de "toda produção da imaginação pela qual o ego busca escapar da dominação da realidade" (tradução nossa). Em Laplanche e Pon- 
talis (1990, p. 152; 1998, p. 169), fantasme, na versão francesa do Vocabulário da Psicanálise, e em sua tradução para "fantasia" na versão portuguesa desse dicionário, aparecem definidos da seguinte forma:"[Cenário] imaginário em que o sujeito está presente e que representa, de modo mais ou menos deformado pelos processos defensivos, a realização de um desejo e, em última análise, de um desejo inconsciente".

Pode-se, com efeito, questionar até que ponto esta concepção platônica de "paixão-sensível" como percepção que se distancia da realidade e se organiza em torno de fantasmas não se aproximaria da noção psicanalítica de "fantasma-fantasia" como fenômeno inconsciente igualmente impreciso e escondendo um significado oculto, recalcado, tal como as sombras da caverna de Platão. Em outras palavras, seria a noção de "paixão-sensível" em Platão a origem semiológica e o embrião da atual noção psicanalítica de "fantasma inconsciente"?

De qualquer forma, ainda que não se possa discutir aqui, com o devido aprofundamento, a questão que se acaba de levantar acima, o que parece ser mais evidente na "Alegoria da Caverna" de Platão é a oposição que o autor faz entre o mundo sensível (a paixão) e o mundo inteligível (a razão), bem como o sentido geral de "paixão-sensível como fato de se sofrer passivamente uma ação", com suas implicações semiológicas mais particulares, no primeiro escalão destas, os sentidos de "paixão como cegueira da realidade","paixão como ilusão sensorial" e "paixão como submissão a uma ação do mundo exterior sobre o corpo".

O sentido de "paixão como escravização" (que evoca, como se viu acima, nesse item, na semiologia do termo adicção) enquanto nuance semiológico do sentido de "paixão como submissão a uma ação do mundo exterior sobre o corpo" aparece mais diretamente enunciado no "Fédon", onde Platão analisa a mesma oposição entre o mundo sensível (a paixão), o corpo, o mundo do homem comum, de um lado, e, de outro, a alma, o mundo inteligível do real, da razão, da verdade, enfim, o mundo do filósofo. O autor escreve, então:

Assim, necessariamente, prosseguiu Sócrates, todas estas considerações fazem nascer no espírito dos filósofos autênticos uma crença capaz de inspirar-lhes nas conversações uma linguagem tal como esta:"Sim,é possível mesmo que haja um caminho que nos oriente quando o raciocínio nos acompanha na pesquisa; e é esta idéia enquanto tivermos o corpo, e nossa alma estiver confundida com essa coisa má, nós não possuiremos jamais suficientemente o objeto do nosso desejo. Ora, este objeto, dizemos, é a verdade. E não somente penas sem fim que o corpo suscita por motivo das necessidades da vida; há também as moléstias e eis aí novos entraves à procura do verdadeiro. Amores, desejos, temores, imaginações de toda espécie, inumeráveis frivolidades, o corpo nos ocupa de tal modo que por ele, como se diz, não nos chega mesmo, realmente, nenhum pensamento sensato, nem um só! 
Considerai as guerras, as dissensões, as pelejas: não há para suscitá-las senão o corpo e suas paixões. A posse de riquezas, eis com efeito a causa original de todas as guerras, e, se somos levados à procura de bens, é por causa do corpo, escravos submetidos ao seu serviço! E é ainda por causa de tudo isso que nos ocupamos pouco de filosofia. Mas o pior de tudo é que quando o corpo nos permite, afinal, um pouco de tranqüilidade, para nos voltarmos para um objeto qualquer de reflexão, as nossas indagações são novamente postas em desordem por este intruso, que nos atordoa, nos perturba e nos desconcerta, a ponto de nos tornar incapazes de distinguir a verdade. Ao contrário, já tivemos realmente a prova de que, se quisermos jamais saber alguma coisa em sua pureza, teremos que nos separar do corpo e olhar com a alma em si mesma as coisas em si mesmas. É, então, ao que parece, que nos pertencerá aquilo de que nos dizemos amantes: 0 pensamento. Sim, quando estivermos mortos, como mostra o argumento, e não durante nossa vida. Se, com efeito, é impossível, na união com o corpo, conhecer algo com pureza, das duas uma: ou não nos é possível, de nenhuma maneira, adquirirmos o saber ou, então, somente será possível quando estivermos mortos, pois será apenas nesse momento que a alma estará em si mesma e por ela mesma, separada do corpo, e não antes.

Além disso, durante o tempo que a nossa vida possa durar, estaremos - segundo parece - o mais perto do saber precisamente quando tivermos o menos possível comércio ou sociedade com o corpo, menos no caso de necessidade maior, quando não estivermos contaminados pela sua natureza, mas que estivermos, pelo contrário, puros de seu contato, até o dia em que o próprio deus tiver posto fim aos nossos liames. Chegados, afinal, desse modo, à pureza, por termos sido separados da demência do corpo, estaremos verossimilmente unidos a seres semelhantes a nós; e por nós, somente por nós, conheceremos aquilo que é isento de impureza. E é nisso, de outro lado, que consiste provavelmente a verdade. Não ser puro e aprender, entretanto, aquilo que é puro; eis, com efeito, como é de temer-se o que não é permitido."Creio que é isto, Símias, que pensam e dizem todos aqueles que são, no sentido verdadeiro o termo, amigos do saber. Assim não te parece? (Platão, 2003, pp. 29-31) ${ }^{5}$

Como se viu acima nesse item, é da paixão que Platão trata quando fala do mundo sensível, do corpo. O sentido de "paixão como escravização" aparece especialmente na passagem acima citada em dois momentos: $1^{\circ}$ Inicialmente, quando o autor fala daquilo que se pode compreender como sendo a submissão, a escravização da alma ao corpo: "enquanto tivermos o corpo, e nossa alma estiver confundida com essa coisa má, nós [os filósofos] não possuiremos jamais suficientemente o objeto do nosso desejo. Ora, este objeto, dizemos, é a verdade"; e $2^{\circ}$ - Em seguida, quando Platão evoca o corpo, ao serviço do qual o filósofo poderá se submeter e se escravizar: "por causa do corpo, escravos [os filósofos] submetidos ao seu serviço!".

Esse sentido de "paixão como escravização" parece, no entanto, possuir outras implicações semiológicas, isto é, conduzir a outras significações 
vizinhas, próximas àquele, especialmente aos sentidos de "paixão como doença", de "paixão como sofrimento" e de "paixão como excesso". Platão escreve, com efeito, na última passagem citada:"E não somente penas [sofrimentos] sem fim que o corpo suscita por motivo das necessidades da vida; há também as moléstias e eis aí novos entraves à procura do verdadeiro". As doenças da alma se apresentam aqui como conseqüência da submissão da alma ao corpo, uma escravização que será tanto maior quanto mais o corpo estiver misturado com a alma na busca do filósofo pela verdade pura. Platão escreve sobre isso na passagem acima citada; vale lembrar: "enquanto tivermos o corpo, e nossa alma estiver confundida com essa coisa má, nós não possuiremos jamais suficientemente o objeto do nosso desejo... a verdade". Na frase:"essa coisa má (o corpo),','má" lembra "mal, doença", conforme aparece na versão francesa dessa passagem, pressupondo assim a idéia de "paixão como sofrimento, como doença".

Em resumo, parece efetivamente que a doença da alma, segundo Platão, não é outra coisa que a paixão considerada enquanto excesso de submissão (escravização) da alma ao corpo, um "sofrimento-doença" dessa alma decorrente da ação do mundo exterior sobre o corpo. Esse sentido de "paixão como escravização", juntamente com suas implicações semiológicas de "paixão como doença e como excesso", parece reforçar a hipótese central deste trabalho, que compara a paixão com a adicção e o tóxico. Esse mesmo sentido parece reforçar também a comparação da paixão platônica com a toxicomania em sua origem semiológica, no contexto médico do final do século XIX, ligada aos sentidos de toxicomania como doença, como degenerescência, como amoralidade e como paixão (ver Bento, 1996, 1999). A degenerescência da toxicomania parece lembrar a degenerescência da paixão em Platão, já que ambas as degenerescências estão relacionadas a uma perda simbólica, isto é, a uma perda da capacidade lógica da natureza humana. A imoralidade parece constituir aqui a conseqüência direta do enfraquecimento dessa lógica, da razão.

Avançando na discussão da comparação entre a paixão platônica e a toxicomania, não se pode esquecer aqui a evolução semiológica desse último termo, a qual desemboca na atual noção de "farmacodependência", uma expressão que surge para substituir o termo "toxicomania". Pretendese, a seguir, citar a definição de "farmacodependência" pela Organização Mundial da Saúde (OMS) para, em seguida, analisá-la e compará-la com a noção platônica de paixão:

Farmacodependência. "Estado psíquico e algumas vezes igualmente físico resultando da interação entre um organismo vivo e um medicamento, se caracterizando por modificações do comportamento e por outras reações, que compreendem sempre uma pulsão de tomar o medicamento de maneira continua ou periódica a fim de reencontrar seus efeitos psíquicos e algumas vezes de evitar o mal-estar da privação. Este estado pode se acompanhar ou 
não de tolerância (tendência a aumentar a dose). Um mesmo indivíduo pode ser dependente de muitos medicamentos". (OMS, 1974, p. 15, tradução nossa)

A partir da análise dessa última citação, pode-se apresentar as seguintes considerações sobre a comparação entre a paixão platônica e essa definição de farmacodependência pela OMS: $1^{\circ}$ - Nessa definição vê-se em destaque o sentido de "farmacodependência como doença que atinge o corpo e o psiquismo", o que evoca a noção platônica de "paixão como doença" que contamina também a alma e o"corpo-sensível", essa última concepção lembrando a imagem de uma "alma corporal", um emaranhado ou mistura do corpo com a alma; $2^{\circ}$ - Vê-se também, na mesma definição, que uma tal doença decorre da dependência tóxica, isto é, da ação continua ou periódica de um medicamento sobre o organismo, o que se parece com o sentido platônico de "paixão como fato de se sofrer a ação do mundo exterior sobre o corpo" e $3^{\circ}$ - Por fim, vê-se ainda a perspectiva de uma ingestão desmedida, excessiva do medicamento, com eventual tendência a tolerância (aumento da dose), o que parece equivaler ao sentido platônico de "paixão como excesso de submissão, de escravização da alma ao corpo".

Avançando na análise dessa última passagem de Platão acima citada, pode-se dizer que ela parece bem resumir o que há de mais essencial no pensamento platônico: o idealismo, a valorização da pré-existência do mundo das idéias em relação ao mundo sensível, das verdades inatas. Vêse que, para Platão, o objetivo da vida só é atingido após a morte. É apenas nesse momento da morte que a alma tem condições de se reencontrar verdadeiramente só, separada e libertada do corpo, podendo, assim, aceder ao conhecimento puro, livre das ilusões produzidas pelo mundo sensível. Só então se dará o retorno às idéias puras que existem a priori da experiência sensível, livres do domínio e influência do mundo exterior. Sobre isso, vale retomar, para sublinhar a importância, Platão escreve, na passagem em questão:

se quisermos jamais saber alguma coisa em sua pureza, teremos que nos separar do corpo e olhar com a alma em si mesma as coisas em si mesmas. É, então, ao que parece, que nos pertencerá aquilo de que nos dizemos amantes: 0 pensamento. Sim, quando estivermos mortos, como mostra o argumento, e não durante nossa vida. Se, com efeito, é impossível, na união com o corpo, conhecer algo com pureza, das duas uma: ou não nos é possível, de nenhuma maneira, adquirirmos o saber ou, então, somente será possível quando estivermos mortos, pois será apenas nesse momento que a alma estará em si mesma e por ela mesma, separada do corpo, e não antes. (Platão, 2003, p. 30) ${ }^{6}$

Essa proposição platônica de combater a paixão e sua conseqüência - a submissão ou escravização da alma ao corpo -, para superar o domínio do mundo exterior sobre o corpo e, assim, aceder ao conhecimento puro,

6 Ver passagem correspondente na edição francesa: (Platon, 1965, p. 115). 
parece conduzir a um "certo paradoxo" em sua teoria das paixões. Sobre isso, Meyer escreverá:

A ambigüidade fundamental da teoria platônica das paixões

Como o leitor deve certamente ter notado,a paixão,em Platão,é simultaneamente o nome de um problema, de que a razão é a solução, e aquilo que por natureza se opõe a qualquer resolução, pois ela [a paixão], devido à cegueira que suscita, impede mesmo a percepção de que haja qualquer problema. Através da paixão apercebemo-nos de que temos que a ultrapassar, mas, por sua causa, não conseguimos conceber algo a procurar para lá dela.Como já dissemos, o paradoxo deve-se ao facto da paixão ser simultaneamente reflexiva e o irreflectido da vida sensível; uma contradição insolúvel, de qualquer modo. (Meyer, 1994, pp. 31-32) ${ }^{7}$

A noção platônica de paixão implica, assim, num "certo paradoxo" em torno da idéia da paixão como sendo, ao mesmo tempo,"reflexiva e o irreflectido da vida sensível,"o motivo e o impedimento da reflexão, a condição e o obstáculo para que exista uma filosofia. Esse mesmo paradoxo reaparece de uma outra maneira através do que se pode compreender como sendo a noção platônica de "alma corporal", ao lado de uma concepção de alma pura, separada do corpo. Essa segunda expressão do paradoxo platônico das paixões aparece mais claramente enunciada numa passagem de A República, onde Platão escreverá:

- Diremos além disso que há pessoas que, quando têm sede, recusam beber?

- Sim, há muitas, que o fazem muitas vezes.

- Então que se dirá acerca delas? Que na alma delas não está presente o elemento que impele mas sim o que impede de beber, o qual é distinto do que impele e superintende nele?

- É o que me parece.

- Porventura o elemento que impede tais atos não provém, quando existe, do raciocínio, ao passo que o que impele e arrasta deriva de estados especiais e mórbidos?

- Acho que sim.

- Não é, portanto, sem razão que consideraremos que são dois elementos, distintos um do outro, chamando àquele pelo qual ela raciocina, o elemento racional da alma, e aquele pelo qual ama, tem fome e sede e esvoaça em volta de outros desejos, o elemento irracional e da concupiscência, companheiro de certas satisfações e desejos (Platão, 2004, p. 135)

Não se poderia ver, na passagem acima citada, o mesmo "certo paradoxo das paixões" na oposição que Platão faz entre razão (alma) e paixão (corpo), por um lado, enquanto, por outro, o autor admite a existência de

7 Ver passagem correspondente na edição francesa (Meyer, 1991, p. 38).

8 Ver passagem correspondente na edição francesa (Platon, 1966, p. 192). 
uma espécie de "alma corporal" nas paixões? Sobre isso, ele escreve nesta passagem: "são dois elementos, distintos um do outro [a oposição entre razão-alma e paixão-corpo], chamando àquele pelo qual ela raciocina, o elemento racional da alma (o que se pode compreender como sendo a alma pura, separada do corpo, racional), e aquele pelo qual ama, tem fome e sede e esvoaça em volta de outros desejos, o elemento irracional e da concupiscência, companheiro de certas satisfações e desejos [a alma corporal]". Como compreender que a alma, em Platão, possa existir dissociada do corpo e, ao mesmo tempo, possuir"o elemento irracional e da concupiscência", passional, corporal? Trata-se aqui de um real paradoxo no seio da obra de Platão, ou, talvez, preferencialmente, de um paradoxo que procede da natureza mesmo das paixões, isto é, de um outro sentido das paixões: 0 "sentido paradoxal das paixões"? Sobre essa segunda expressão do sentido paradoxal das paixões em Platão, Meyer escreverá:

Platão opõe claramente, na própria alma, o desejo que deriva do corpo - e que associa a uma afecção doentia, patológica, que nos importuna - e o logos... Aceitamos facilmente que as paixões constituam nossa corporeidade, mas que existam também na alma como movimentos corporais ou, pior, como doenças, isso já é mais enigmático... De qualquer modo, a idéia das paixões como afecções corporais da alma levanta efectivamente problemas e Platão, em vez de os resolver, vai, pelo contrário, induzi-los na filosofia, de modo a tornar esta possível por meio da oposição entre a alma e o corpo. (Meyer, 1994, pp. 26-27) ${ }^{9}$

Vê-se que Meyer, na passagem acima citada, expressa claramente que não existe dúvida quanto ao fato de que "paixões constituam nossa corporeidade" e se interroga sobre a concepção "enigmática" das "paixões como movimentos corporais na alma", das "paixões como afeç̧ões corporais na alma". Mais precisamente, parece que um "certo paradoxo" é colocado em evidência em Platão quando, por um lado, se vê a suposição da existência de uma "alma corporal", de "paixões da alma", enquanto que, por outro, pode-se também encontrar uma oposição clara entre "paixão-corpo" $x$ "razão-alma".

Para se aprofundar na questão de saber se este "certo paradoxo" das paixões constitui um real paradoxo no seio da obra de Platão, ou, preferencialmente, um paradoxo que procede da natureza mesmo das paixões, persistindo, assim, na sua história, pretende-se, no item seguinte, examinálo a partir da Renascença. Mas por que apenas a partir da Renascença? Por que não em algum outro período histórico situado após a Antiguidade grega e antes da Renascença? Para responder, caberia evocar a definição de "Renascença": "desenvolvimento intelectual provocado, a partir do século XV na Itália, depois em toda Europa, pelo retorno às idéias, à arte antiga greco-latina. - Período histórico indo do século XIV ou do XV ao final do século XVI" (Robert, 1992, p. 1661, tradução nossa). Sabendo-se, então,

9 Ver passagem correspondente na edição francesa (Meyer, 1991, pp. 32-33). 
que será aproximadamente a partir do século XV que se dará o retorno e desenvolvimento das idéias da Antiguidade grega, pretende-se, então, no item seguinte, discutir se particularmente esse "certo paradoxo" platônico das paixões, no conjunto amplo das idéias da Antiguidade grega, também não teria sido retomado e desenvolvido a partir da Renascença.

O sentido paradoxal das paixões em Platão persistiria a partir da Renascença, especialmente em Descartes e em Freud?

Esse "certo paradoxo" platônico das paixões parece persistir na história, posto que poderá ser reencontrado no pensamento de outros autores clássicos, principalmente em Descartes (1994, 1998), em As paixões da alma. Sobre essa ponte entre Platão e Descartes, Meyer escreverá:

Se há um pendor idealista no cartesianismo, é aqui que ele se exprime com mais força.

A consciência é sempre consciência de si. A transparência parece ser a tal ponto total que impregna a criança logo à nascença. A criança, mal possui uma alma, sabe desde logo que a possui e sabe também o que ela contém, pois Deus constitui-a assim. Mas, por outro lado, de um modo bastante contraditório, Descartes precisa que as primeiras idéias que surgem ao espírito são confusas, pois nascem das impressões que marcam o corpo.

Contudo, a criança sabe que conhece e, desse modo, conhece aquilo que sabe [inatismo]. (Meyer, 1994, p. 161) $)^{10}$

Nesse comentário sobre a história das paixões no campo da filosofia, vê-se que Meyer destaca o importante papel de Descartes particularmente na história do idealismo, posto que será em Descartes que o idealismo platônico "se exprime com mais força". Vê-se também, na última passagem acima citada, que Descartes retoma o mesmo paradoxo platônico das paixões, posto que ele admite, por um lado, a existência de uma "alma corporal", enquanto "primeiras idéias que surgem ao espírito... confusas, pois nascem das impressões que marcam o corpo",e, por outro, ele vê a perspectiva da alma se apresentar pura e dissociada do corpo, como uma herança divina constituída por idéias inatas e, por conseqüência, existindo a priori da experiência sensível.

E no que concerne à psicanálise, pode-se admitir, lá também, uma influência do platonismo, especialmente do paradoxo platônico das paixões, em Freud? Lendo os comentadores de Platão e Freud, particularmente Meyer $(1991,1994)$ e Green $(1988,1990)$, se pode encontrar uma referência ao conceito de "pulsão" em Freud como central em psicanálise e análogo à concepção platônica de "paixão como expressão da existência de uma 'alma corporal'.'. No entanto, a partir desses mesmos comentadores, não se encontra nenhuma referência direta à ponte entre Platão e Freud no que concerne particularmente à retomada por Freud do "sentido paradoxal das

Ver passagem correspondente na edição francesa (Meyer, 1991, p. 192). 
paixões" em Platão. Mais precisamente, parece que, pelo menos de um ponto de vista teórico, o conceito freudiano de "pulsão-paixão" não comporta nenhum paradoxo. Para melhor explicar essa afirmação, será citada a seguir uma passagem de um notável trabalho de Green sobre essa "paixãopulsão" freudiana:

Paixão-pulsão

Todos os autores estão de acordo em "localizar" a paixão na união da alma com o corpo, sejam eles cartesianos ou não. Freud não pertence a essa filiação. Mas aquela da qual eleé a descendência não foge a essa tradição.Porque ele aprendeu a psiquiatria com Griesinger, cujas preocupações giravam em torno desse problema, como testemunham os trabalhos de Paul Guiraud, principal defensor, na escola francesa da geração precedente, de um "psiquismo subcortical", isto é, hipotalâmico.

Retomemos a definição do conceito central da psicanálise - não o inconsciente, mas as pulsões -, "nossa mitologia". Citarei (a seguir) a definição que Freud lhes dá, ali intercalando com meu próprio comentário (entre colchetes e em itálico).

"Se [hipótese] nos situando de um ponto de vista biológico [adotando o vértice' da ciência da vida, a saber, do ponto de vista do corpo somático] consideramos agora a vida psíquica [a vida do espírito], o conceito de "pulsão" [o conceito, e não o fenômeno, de pulsão, entre aspas] nos aparece como um conceitolimite [conceito no limite daquilo que se pode conceitualizar], entre o psíquico e o somático [conceito-limite no limite, no encontro do psíquico e do somático], como o representante psíquico das excitações que saem do interior do corpo e chegam ao psiquismo [o conceito de pulsão remete a noção de representação psíquica; deslocamento semântico: aquilo que estava entre o psíquico e o somático, representante psíquico das excitações saídas do interior do corpo - dito de outra maneira, a pulsão, ainda que localizada entre o psíquico e o somático, tendo adquirido o estatuto de representante psíquico, oscila por sua vez quando ela chega na vizinhança do psíquico, ainda que ela tenha nascido no interior do corpo], como uma medida da exigência de trabalho [medida, logo quantidade, a trabalhar, isto é, a transformar] que é imposta ao psíquico em conseqüência de sua ligação com o corporal [o psíquico sofre a quantidade vinda do corpo ao qual ele está ligado - dito de outra maneira, este psíquico é o escravo do corporal, a quem é imposto o trabalho de um corpo que não trabalha desta maneira, mas o faz trabalhar.]

Estamos tão longe da paixão? A paixão se opõe à ação, como sofrer [pâtir] é o contrário de agir. $\mathrm{O}$ Ego sofre a pulsão, como o psiquismo [na pulsão] sofre o corporal. O sujeito sofre de sua paixão. Ele não é mais agente, mas paciente. A paixão domina o sujeito, ela subverte sua razão - na verdade, seu psiquismo inteiro. Ela o aliena a seu objeto. Ela comanda suas ações. Ele não age mais; ele é agido, em reação, ele passa ao ato. (Green, 1990, pp. 164-166, tradução nossa) ${ }^{11}$

Se Green não evoca diretamente, aqui, o nome de Platão e nem, então, a "ponte Platão-Freud",ele faz, em compensação, uma referência explícita à

11 Ver passagem correspondente na edição brasileira (Green, 1988, pp. 234-236). 
pulsão freudiana como sendo um "conceito central da psicanálise", um "um conceito-limite...entre o psíquico e o somático",análogo à noção de "paixão como fato de se sofrer passivamente uma ação."Mais precisamente, Green, na passagem acima citada, começa por afirmar que "todos os autores estão de acordo em 'localizar' a paixão na união da alma com o corpo, sejam eles cartesianos ou não". Em seguida, o autor evoca a seguinte passagem de Freud:"o conceito de 'pulsão'... nos aparece como um conceito-limite... entre o psíquico e o somático". Green terminará por aproximar esse conceito da noção originária de paixão, posto que, se interrogando sobre a pulsão freudiana, ele escreverá: “Estamos tão longe da paixão? A paixão se opõe à ação [o que lembra as origens etimológicas de paixão como sujeição a uma ação], como sofrer [pâtir em francês] é o contrário de agir. O Ego sofre a pulsão, como o psiquismo [na pulsão] sofre o corporal. O sujeito sofre de sua paixão". A analogia "paixão-pulsão" aparece ainda em Green no título do item do qual se retirou a passagem acima citada, e também no título principal do seu trabalho: "Paixões e destinos das paixões", parafraseando Freud (1915/1974) no trabalho intitulado:"Pulsões e destinos das pulsões", traduzido para o português como "Os instintos e suas vicissitudes".

Esse conceito-limite freudiano de pulsão - entre o psíquico (alma) e o somático (corpo) -, remetendo, então, ao mesmo tempo, a um pouco de psíquico e a um pouco de somático, isto é, a uma espécie de "pulsão como psiquismo corporal", não evoca, ele, a noção platônica de "paixão como expressão de uma alma corporal"? Ainda que não exista em Green (1988, 1990) referência direta ao nome de Platão, é, no entanto, nesse autor que o leitor é levado a pensar quando lê essa passagem de Green acima citada.

De qualquer forma, não se encontra em Green $(1988,1990)$ nenhuma referência direta à "ponte Platão-Freud", nem muito menos à retomada do paradoxo platônico das paixões no conceito de "paixão-pulsão" de Freud. Caberia lembrar que o paradoxo platônico das paixões foi analisado no item anterior como relacionado ao fato de se admitir, por um lado, a existência de um elemento irracional, concupiscível, passional, corporal na alma (a"alma corporal") e, por outro lado, ao mesmo tempo, a possibilidade de existência de uma alma pura, dissociada do corpo. Mais precisamente, foi justamente o idealismo platônico, valorizando essa alma pura, expurgada das paixões, ao lado da concepção platônica de uma "alma corporal", que introduziu, no item anterior, o "sentido paradoxal das paixões" em Platão. Se Freud retoma a noção platônica de "paixão como expressão de uma alma corporal" sem seu sentido paradoxal, como se supõe aqui, para onde teria ido o paradoxo que envolvia essa noção? Num primeiro olhar, esse paradoxo parece ter desaparecido, posto que as paixões, teoricamente, passaram a ser aceitas em Freud como parte do espírito humano. A esse respeito, assinalam Laplanche e Pontalis (1990, p. 361;1998, p. 395):“a teoria das pulsões em Freud se mantém sempre dualista", o que significa que, em Freud, as paixões e o corpo não serão mais banidos da alma humana. 
No campo da filosofia, pode-se encontrar um trabalho tão notável quanto aquele que Green $(1988,1990)$ realizou no campo da psicanálise, onde a "ponte Platão-Freud" é diretamente mencionada e de onde se poderá extrair igualmente uma aproximação entre a noção platônica de "alma corporal" e o conceito freudiano de "pulsão (entre o psíquico e o somático)". Trata-se do trabalho de Meyer, de onde se pode citar a seguinte passagem, abordando as questões agora em destaque:

Se (as paixões) fazem parte da alma, elas são juízos, representações de impulsos sensíveis. E pensamos imediatamente em Freud. Note-se, aliás, a estreita semelhança entre o modelo platônico da alma e aquilo que, vinte e cinco séculos mais tarde, Freud dirá sobre ela. (Meyer, 1994, p. 26) ${ }^{12}$

Para discutir aquilo que se pode compreender como sendo a resolução teórica, por Freud, do paradoxo da teoria platônica das paixões, serão citadas, a seguir, três passagens de Meyer que podem conduzir a essa conclusão. São elas:

$1^{\circ}$ - Meyer escreverá inicialmente:

O Renascimento vai marcar a História através de uma lenta dissolução do agostinianismo que, por outro lado, vai renascer regularmente das suas cinzas como que para contrabalançar o deixar-andar das paixões.

O juízo teológico é substituído pela análise. O homem pode-se compreender a partir de si próprio sem ter que passar por Deus e pelos seus padres. A realidade humana pode reflectir-se (Descartes) sem que tenha ainda que se referir ao acontecimento mítico da Queda (de Adão e Eva). (Meyer, 1994, p. 105) ${ }^{13}$

$2^{\circ}$ - Mais adiante, Meyer prosseguirá:

Pois temos que compreender uma coisa: a paixão é facto da consciência e, longe de poder ser varrida pela moral ou pela política, é aí que surge para melhor fazer valer as suas exigências.

Toda a questão consiste agora em saber em que medida a passionalidade é uma estrutura do espírito humano. Para responder a esta interrogação temos que voltar a mergulhar na teoria da consciência tal como foi inaugurada por Descartes e seguir o fio que nos leva até Kant.Toda a nossa modernidade se joga nesta história da consciência, até a sua superação por Freud, Nietzsche ou Marx. (Meyer, 1994, p. 155) $)^{14}$

$3^{\circ}$ - Finalmente, mais adiante ainda, Meyer acrescentará:

No entanto, com o desaparecimento da subjectividade pura (e não só da consciência) e a assimilação da subjectividade ao indivíduo, as paixões não

Ver passagem correspondente na edição francesa (Meyer, 1991, p. 186). 
podiam deixar de ressurgir como expressão das diferenças individuais. Se houvesse ainda um universalismo em Marx ou Freud e até em Nietzsche, hoje em dia, com o questionamento de toda a realidade antropológica para além da individual e o afundar das ideologias, esse universalismo, que é o abrigo tradicional das paixões, não podia deixar de, por sua vez, também se afundar. A tolerância relativamente ao Outro que, por vezes, é codificada em termos de "direitos do homem", conduz à admissão, pelo menos a nível teórico, das suas paixões. Mas, até que ponto, tanto em termos de direito como de facto? (Meyer, 1994 , p. 241) $)^{15}$

Pode-se, então, ver que, a partir da Renascença, não se fará mais a caça ao "deixar-andar das paixões". "Toda... questão [consistirá doravante]... em saber em que medida a passionalidade é uma estrutura do espírito humano." Em sua abordagem histórico-filosófica das paixões, Meyer (1991, 1994) responderá inicialmente essa indagação colocando em evidência a aceitação das paixões "na teoria da consciência tal como foi inaugurada por Descartes." Depois, esse autor sublinhará a ultrapassagem das teorias da consciência especialmente com “Freud, Nietzsche ou Marx."Finalmente, o mesmo autor terminará por destacar a tendência que, atualmente, "conduz à admissão, pelo menos a nível teórico, das... paixões" (itálicos nossos) e por se questionar "até que ponto tanto em termos de direito como de facto" as paixões passarão a ser aceitas.

Vê-se também, nas últimas passagens citadas, que não se tratará, para Meyer $(1991,1994)$, de atribuir uma deferência particular a Freud, nem a nenhum outro autor. Seu objetivo aqui parece ser descrever uma cadeia histórica na qual figuram alguns dos principais pensadores das paixões, dentre esses, Freud. O que se compreende neste trabalho como sendo " $a$ resolução teórica, por Freud, do paradoxo da teoria platônica das paixões" constitui, então, uma conclusão a que se chegou indiretamente a partir das considerações gerais de Meyer $(1991,1994)$ sobre a história da natureza humana e a partir da preocupação do autor deste trabalho em destacar e situar particularmente Freud nesse contexto histórico amplo descrito por Meyer. Tal preocupação com Freud se justifica pelo objetivo deste artigo de constituir uma abordagem psicanalítica. Dito de outra maneira, a ênfase colocada aqui em Freud em particular não significa que se esteja afirmando que Freud foi o único autor a propor uma solução teórica para o paradoxo platônico das paixões.

Chegou-se, também, aqui, a essa conclusão sobre a"resolução teórica, por Freud, do paradoxo da teoria platônica das paixões" através da leitura e análise do trabalho de Green (1988, 1990), cuja abordagem psicanalítica marcou, por sua vez, uma deferência particular feita a Freud. Tal deferência a Freud não impedirá Green, por outro lado, quando se volta à análise das Cinco Psicanálises (Dora, Schreber, Homem dos Ratos, Homem dos Lobos e Pequeno Hans) de Freud (1954/1992), de se interrogar sobre "As paixões e 15 Ver passagem correspondente na edição francesa (Meyer, 1991, p. 285) 
os destinos das paixões" na cura analítica, de criticar Freud por ter banido da cura analítica a vivência da "loucura passional" em nome da preocupação com o discurso sobre essa "loucura", substituindo, assim, a atitude de assistir à crise dessa loucura por um olhar frio, lúcido e objetivo sobre esse discurso. Isso não seria o mesmo que dizer que, de um ponto de vista teórico, Freud parece aceitar as paixões como sendo uma estrutura do espírito humano e um elemento indispensável para a análise da neurose de transferência, ainda que, do ponto de vista da cura psicanalítica, esse autor rejeite as paixões pelo fato delas oporem uma resistência ao processo analítico devido ao seu poder de cegueira? Não se deveria evocar Meyer $(1991,1994)$ para questionar, transpondo sua indagação do campo da filosofia para o campo psicanalítico, "até que ponto, tanto em termos de direito como de facto", Freud aceitará as paixões?

Se se trata em Freud de uma aceitação apenas teórica das paixões, isso não equivale a dizer que persistirá nesse autor uma "certa rejeição" das paixões? Se sim, não se reencontra, então, em Freud, "pelo menos parcialmente", o mesmo paradoxo da teoria platônica das paixões: a concepção de uma "alma corporal" (a "pulsão-paixão" entre o psíquico e o somático) e, ao mesmo tempo, a valorização de uma alma pura, libertada das paixões (a "pulsão-paixão" enquanto discurso objetivo, representação simbólica pura, livre da vivência e da passagem ao ato passional)? Em caso de resposta afirmativa, tratar-se-ia aqui de um paradoxo que Freud retomou de Platão? Ou, de preferência, tratar-se-ia de um paradoxo presente tanto em Platão quanto em Freud, expressivo da natureza mesmo das paixões, revelador, assim, de um outro sentido das paixões - o seu sentido paradoxal - e da natureza humana igualmente paradoxal?

Para se aprofundar no debate dessas questões levantadas no parágrafo anterior e concluir essa pesquisa sobre os sentidos da paixão na Antiguidade grega, passa-se, a seguir, ao último item deste trabalho, onde se discutirá a indagação central se o phármakon platônico seria a origem semiológica dos sentidos"tóxico" e paradoxal das paixões em geral.

\section{Considerações finais: Seria o phármakon platônico a origem semiológica dos sentidos "tóxico" e paradoxal das paixões em geral?}

Para introduzir a discussão sobre a questão central deste item, expressada em seu título, será necessário analisar um último sentido da paixão:" paixão como fraqueza da vontade". De uma maneira geral e à primeira vista, os gregos associam a força ao logos, que seria da natureza humana, opondo esse logos à paixão, esta vista aparentemente como sendo o efeito da cegueira que resulta da dominação que o mundo exterior exerce sobre o corpo, signo da fraqueza humana, da submissão da alma ao corpo em 
detrimento da razão. Essa ênfase colocada numa tal dominação do mundo exterior parece implicar, por outro lado, na dimensão social e relativa das paixões, por oposição a razão, que se situaria do lado do Bem supremo, do universal. Os homens afirmariam, assim, suas diferenças pelas diferenças existentes entre suas paixões, suas vontades, suas fraquezas, enquanto que a razão permitiria que eles pudessem se reunir todos na mesma e única condição humana. A esse respeito, Meyer escreverá:

Mas temos que ter em conta que nem toda a gente deseja a mesma coisa, como se pudéssemos fraquejar perante o Bem supremo, preterindo-o face a esses pequenos desejos. Aristóteles irá falar de ignorância, como Platão, ou de fraqueza da vontade? Mas os Gregos não conhecem a vontade como uma faculdade autônoma: aquilo que obriga o desejo só pode ser a razão, e aquilo que o torna dominante a paixão. $\mathrm{O}$ homem que está cego perante o Bem supremo é o homem das paixões: recusa-se a ver e, quer se explique isso pela racionalização, como um falso saber, ou pela ilusão passional que nos leva a julgar de um modo incorrecto ou a desejar demasiado e, desse modo, a tender fracamente para o que é justo, tudo isto confirma o carácter funesto das paixões como tais. (Meyer, 1994, pp. 68-69) ${ }^{16}$

Vê-se, então, na passagem acima citada, que, entre os gregos, "aquilo que obriga o desejo só pode ser a razão"; a força é a razão que se opõe aos "pequenos desejos", esses remetendo ao "homem das paixões", e essas "paixões" sendo vistas como "fraqueza da vontade" - aquela do "homem que está cego (ao) Bem supremo", ao logos -, como não constituindo uma "faculdade autônoma" da natureza humana, um universal humano (o"Bem supremo", a razão), mas, ao contrário, como associadas ao caráter relativo do homem (pelo fato de "que nem toda a gente deseja a mesma coisa") e à sua dimensão social.

O sentido oposto a"paixão como fraqueza da vontade",a saber, aquele de "paixão como força-logos", parece, num primeiro olhar, ter surgido a partir da Renascença, momento histórico onde se viu claramente nascer uma aceitação explícita das paixões tanto no nível de sua vivência cega quanto de sua compreensão lógica. Essa é, pelo menos, a primeira conclusão a que se chega quando se lê a passagem de Meyer (1991, p. 127-128; 1994, p. 105) citada no item anterior. Como se viu, segundo esse autor nessa passagem, a partir do Renascimento, de fato, não se fará mais a caça ao "deixar-andar das paixões"; doravante "o homem [poderá se] compreender a partir de si próprio sem ter que passar por Deus e pelos seus padres"; "a realidade humana [poderá ser refletida] (Descartes) sem que tenha ainda que se referir ao acontecimento mítico da Queda (de Adão e Eva)".

Mais precisamente, vê-se que, a partir da Renascença (Renascimento), se, por um lado, se guardará do grego antigo o sentido de "paixão como fraqueza da vontade" associada à cegueira da razão e a concepção de força

16 Ver passagem correspondente na edição francesa (Meyer, 1991, p. 82). 
como ligada ao logos", por outro, se acrescentará, aparentemente, no entanto, um novo sentido das paixões oposto ao primeiro: "paixão como força (paixões racionais)", o que, aliás, enquanto conjunto, reforçará o "sentido paradoxal das paixões."Meyer escreverá sobre isso:

Desde a Renascença que as paixões fazem parte das observações [sobre o homem] feitas por escritores, moralistas e filósofos...

A grande viragem do agostinianismo, que encerrava o homem no pecado, permite integrar as paixões no seio do discurso, tornando-as racionais, apesar de serem paixões. É aí que reside todo o paradoxo das paixões. Elas exprimem uma racionalidade subjacente à nossa cegueira e aos nossos desregramentos, formam uma razão sob o caos das aparências e até da História. O discurso sobre as paixões liberta delas a razão, abolindo-as e preservando-as, abolindo-as para o observador que está de fora e que se debruça sobre os actores que a paixão [captura com armadilhas] (Meyer, 1994, pp. 151-152) ${ }^{17}$

Se, a partir da Renascença, as paixões "exprimem uma racionalidade subjacente à nossa cegueira e aos nossos desregramentos, formam uma razão sob o caos das aparências e até da História", não se poderia, assim, compreender que o sentido de "paixão como força" irá, doravante, se ligar à idéia da existência de uma espécie de "logos inconsciente" oculto no interior das paixões aparentemente cegas e fracas?

No que concerne à história da natureza humana, tudo pareceria, então, se passar como se, partindo em Platão do culto a um homem livre para pensar suas paixões, mas não para vivenciá-las, se passasse pelo cristianismo, especialmente pelo mito de Adão e Eva, pela interdição de comer a maçã (fruto-símbolo das paixões e do conhecimento do Bem e do Mal - ver análise a esse respeito em Bento, 1996) e pelo ideal de um homem interditado de pensar e viver suas paixões, até culminar, a partir da Renascença, no ideal de um homem capaz, de novo, de pensar suas paixões, mas sem se abandonar a elas sem culpabilidade, sem que lhe seja interditada a vivência passional em demasia, em excesso.

Essa liberdade para vivenciar as paixões até um certo ponto surgindo, aparentemente, a partir da Renascença, teria, então, limites: a aceitação dessa vivência seria possível na condição de que se pudesse ter um certo controle sobre os excessos passionais, o que permitiria uma espécie de equilíbrio entre a vivência e a elaboração lógica das paixões, a intervenção de um logos passional associado à força das paixões, de maneira a dominar a cegueira associada à sua fraqueza. $O$ sentido de "paixão como força" seria, então, aceito ao lado daquele de "paixão como fraqueza da vontade". Uma ilustração notável dessa idéia é dada por Descartes quando o autor conclui sua última obra publicada em 1644, o Tratado das paixões da alma, escrevendo, no seu último artigo (212):

17 Ver passagem correspondente na edição francesa (Meyer, 1991, pp. 181-182). 
Que é apenas delas que dependem todo o bem e todo o mal desta vida

De resto, a alma pode ter seus prazeres à parte. Mas quanto aos que lhe são comuns com o corpo, dependem inteiramente das paixões, de forma que os homens que elas mais podem emocionar são capazes de desfrutar de mais doçura nesta vida. É verdade que também podem encontrar mais amargura, quando não sabem empregá-las bem e quando o acaso lhes é adverso. Mas a sabedoria é útil principalmente no ponto em que ensina a dominá-las tão bem e a manejálas com tanta habilidade que os males que causam são muito suportáveis e até mesmo se obtém alegria de todos eles (Descartes, 1998, p. 174) ${ }^{18}$

Vê-se nessa passagem que, num momento tão importante como esse, quando Descartes conclui e escreve o último artigo de sua última obra, sua preocupação não era fazer uma caça à vivência passional, pois ele escreve:"os homens que elas [as paixões] mais podem emocionar são capazes de desfrutar de mais doçura nesta vida". Tratar-se-á, ao contrário, aqui, de valorizar essa vivência acrescendo-lhe um logos, um cogito para controlá-la, mais precisamente, para evitar os excessos passionais, pois:"a sabedoria [o logos, o cogito]... ensina a [dominar as paixões] tão bem e a manejá-las com tanta habilidade que os males que causam são muito suportáveis e até mesmo se obtém alegria de todos eles".

Não se poderia dizer que, em Descartes, na passagem acima citada, "pensar as paixões" como meio de controlá-las se transforma em expressão da potência, da força humana, a sabedoria tornando o homem dominador de suas paixões? Também não se poderia dizer que esse sentido de"paixão como fraqueza da vontade" é sugerido na mesma passagem pela idéia dos males que as paixões causam devido a seu efeito de cegueira do logos?

Se dizia mais acima nesse item que, à primeira vista, o sentido de "paixão como força" (paixões racionais) teria aparecido a partir da Renascença. Tendo sido esse período histórico marcado pelo retorno às idéias e à arte greco-latinas antigas, caberia agora questionar se as origens semiológicas desse sentido de "paixão como força", como as demais idéias renascentistas, também não encontraria suas origens semiológicas entre os gregos, mais precisamente na lenda de Pigmalião, assim descrita por Grimal:

PIGMALIÃO... rei de Chipre, que se apaixonou por uma estátua de marfim representando uma bela mulher, que ele próprio teria esculpido, segundo uma das versões da lenda. Abrasado de paixão, pediu a Afrodite que lhe enviasse uma mulher semelhante à estátua. As súplicas dirigidas à deusa numa das festas em sua honra foram ouvidas: ao chegar a casa, Pigmalião apercebeu-se de que a figura de marfim ganhara vida. Desposou-a e dela teve uma filha chamada Pafo, mãe de Cíniras. (Grimal, 1993, p. 373) ${ }^{19}$

18 Ver passagem correspondente na edição francesa (Descartes, 1994, p. 218).

19 Ver passagem correspondente na edição francesa (Grimal, 1991, p. 401). 
Essa paixão de Pigmalião, que possui a força da criação artística, que cria seu próprio objeto, não evocaria esse sentido de "paixão como força (paixões racionais)"? E o logos passional que se liga ao sentido de "paixão como força",a partir da Renascença, não seria uma forma de criação simbólica do objeto passional análogo à criação artística do objeto da paixão de Pigmalião?

Se se aprofunda ainda mais as origens semiológicas, entre os gregos, deste sentido de "paixão como força" associado à idéia da existência de um "logos passional", visível ou oculto, mas sempre presente ao lado do sentido de "paixão como fraqueza da vontade (cegueira)", a partir da Renascença, e se desloca do campo da "paixão amorosa" (tradução portuguesa da expressão francesa passion amoureuse, aqui empregada para se referir ao sentido particular e restrito da paixão entre dois amantes, em oposição ao sentido amplo do termo "paixão" entre os gregos que a entendiam, viu-se no primeiro item, como passividades diversas diante do fato de se sofrer genericamente uma ação) na lenda de Pigmalião para o campo da toxicomania, com a finalidade de analisar a hipótese central deste trabalho, que compara a paixão com o tóxico, se é, então, tentado a evocar o phármakon da Antiguidade grega, especialmente como o apresenta Derrida em A farmácia de Platão, se inspirando para tal no Fedro de Platão. Mais precisamente, se pretende fazer aqui uma alusão a narrativa do mito de Theuth, que aparece nesse escrito, onde o phármakon é descrito como sendo, ao mesmo tempo, logos (razão, força) e "filtro de esquecimento" (cegueira, fraqueza da vontade);"remédio" e "droga";"contra-veneno" e "veneno"; "medicina"," possibilidade de salvação", de "imortalidade da alma", assim como de doença e de morte da alma. Compreende-se, finalmente, que se trata aqui de um "phármako-logos" em sentido amplo, posto que ele "[abriga] nele mesmo essa cumplicidade dos valores contrários". Derrida escreverá a esse respeito:

E passa-se então ao diálogo sobre a essência da sabedoria, o melhor phármakon, o remédio capital.

A filosofia opõe, pois, ao seu outro, essa transmutação da droga em remédio, do veneno em contraveneno. Uma tal operação não seria possível se o phármakológos não abrigasse nele mesmo essa cumplicidade dos valores contrários, e se o phármakon em geral não fosse, antes de toda discriminação, o que, dandose como remédio, pode (se) corromper em veneno, ou o que se dando como veneno pode se verificar remédio, pode aparecer depois de administrado em sua verdade de remédio. A "essência" do phármakon é que, não tendo essência estável,nem caráter"próprio",nãoé,em nenhum sentido dessa palavra (metafísico, físico, químico, alquímico), uma substância. O phármakon não tem nenhuma identidade ideal, ele é aneidético, e primeiro porque ele não é monoeidético (no sentido em que o Fédon fala do eîdos como de um simples: monoeidés). Esta "medicina" não é um simples.... 
Esta não-substância farmacêutica não se deixa manejar com toda segurança nem em seu ser,já que ela não o tem, nem em seus efeitos, que podem incessantemente mudar de sentido. Assim, a escritura, anunciada por Theuth como um remédio, como uma droga benéfica, é em seguida devolvida e denunciada pelo rei, depois, no lugar do rei, por Sócrates, como substância maléfica e filtro do esquecimento. Inversamente, e ainda que a legibilidade não seja imediata, a cicuta, essa poção que nunca teve outro nome no Fédon senão o de phármakon, é apresentada a Sócrates como um veneno, mas ela se transforma, pelo efeito do lógos socrático e pela demonstração filosófica do Fédon, em meio de libertação, possibilidade de salvação e virtude catártica. A cicuta tem um efeito ontológico: iniciar à contemplação do eîdos e à imortalidade da alma. Sócrates a toma como tal. (Derrida, 1968/1997, pp. 73-74)20

Uma parte dessa passagem de Derrida constitui a epígrafe que abre o livro de Le Poulichet (1987), intitulado Toxicomanias e Psicanálise. As toxicomanias são aqui situadas "mais além da 'toxicomania'" e definidas como "operação do phármakon" (p.41). Essa proposição aparecerá apenas no segundo capítulo desse livro, após um primeiro capítulo onde a autora critica as teorias da toxicomania que, ainda que se pretendendo psicanalíticas, colocavam a ênfase na abordagem da substância química e do comportamento de se intoxicar, esquecendo, assim, que, em psicanálise, a essência de toda pesquisa deve ser o sujeito do inconsciente. Dito de outra maneira, parece que foi com a preocupação de conduzir uma investigação rigorosa em psicanálise das toxicomanias que Le Poulichet propôs a "operação do phármakon","mais além da 'toxicomania"'. Tal compreensão da "toxicomania" não aparecerá sem primeiro evocar as origens semiológicas dessa operação - na epígrafe mesmo do seu livro -, origens que remeteriam efetivamente ao phármakon de Platão tal como analisado por Derrida especialmente na passagem desse autor acima citado.

Nessa mesma passagem de Derrida, se pode ler que o "phármakon" não é uma substância:"A 'essência' do phármakon é que, não tendo essência estável, nem caráter 'próprio', não é, em nenhum sentido dessa palavra (metafísico, físico, químico, alquímico), uma substância". E, a esse respeito, Le Poulichet escreverá, no final do seu primeiro capítulo crítico, a título de introdução da sua proposição da "toxicomania como operação do phármakon", que aparecerá no capítulo seguinte (o capítulo 2):

Eu tentarei num primeiro tempo especificar as qualidades desta operação, afastando-me dos modelos psicofarmacológicos. É apenas após ter apreciado as características desta operação do phármakon - que não é equivalente ao uso de drogas - que eu examinarei o tipo de formação ao qual ela pertence. Apenas neste momento eu abordarei o lugar desta formação nas diferentes toxicomanias. (Le Poulichet, 1987, p. 39, tradução nossa) 
Mais adiante, a mesma autora precisará:"Pode-se já pressentir que o verdadeiro tóxico - aquele que nos ocupa numa clínica psicanalítica - não é provavelmente a droga em si!" (Le Poulichet, 1987, p. 73, tradução nossa).

Segundo Le Poulichet (1987), a ênfase colocada pelas teorizações psicanalíticas no comportamento de se intoxicar e na substância tóxica leva a "desnaturar os conceitos analíticos" (p.17). Se questionando se "as teorias de inspiração psicanalítica que se consagram à questão das toxicomanias não teriam herdado o modelo médico de pensamento do tóxico" (p. 12), a autora termina por considerá-las como uma "psicologização secundária dos conceito analíticos" (p. 12) aplicadas ao fenômeno da toxicomania segundo "um modelo que toma emprestado a lógica mesmo das crenças em vigor na velha medicina positivista" (pp. 25-26, traduções nossas).

No que concerne à hipótese central deste trabalho, deve-se precisar desde logo que, por um lado, não se encontra em Le Poulichet nenhuma indicação direta sobre a comparação entre a paixão e o tóxico. No entanto, por outro lado, a autora propõe a "operação do phármakon" enquanto teorização rigorosa em termos de abordagem psicanalítica das toxicomanias e, além disso, se refere à aparição do termo toxicomania no meio médico do final do século XIX associado ao sentido de "toxicomania como paixão" (itálicos nossos). Le Poulichet terminará por deplorar a perda dessa acepção no campo da reflexão psicanalítica sobre as toxicomanias, assim escrevendo:

Precisamente, uma certa psicanálise pode validar este duplo empreendimento de medicalização e de psicologização das toxicomanias. A figura plural da "paixão", que dominava no século XIX para dar conta das toxicomanias e que não separava o corpo da "alma", teria constituído uma base mais propícia à reflexão psicanalítica, conservando a dimensão subjetiva e enigmática da experiência. (Le Poulichet, 1987, p. 13, tradução nossa)

Como compreender essa dupla valorização em Le Poulichet (1987), por um lado, do sentido de "toxicomania como operação do phármakon" e, por outro, daquele de "toxicomania como paixão"? Existiria uma analogia entre esses dois sentidos? Seria o phármakon de Platão a origem semiológica do sentido de "toxicomania como paixão", que surge no meio médico do final do século XIX? Não se poderia considerar esse "phármakon" platônico, do qual "a 'essência'... não é, em nenhum sentido dessa palavra... uma substância" - "esta não-substância farmacêutica" - como sendo a paixão? Se sim, isso não equivaleria a dizer que são as paixões em geral que intoxicam? Mais precisamente, não constituiria o phármakon de Platão a origem semiológica dos sentidos "tóxico" e paradoxal das paixões em geral associadas, ao mesmo tempo, à fraqueza e à força, à cegueira e à razão etc.?

Com efeito, embora só aparecendo à primeira vista a partir da Renascença, não pareceria que o sentido de "paixão como força-logos" encon- 
tra sua origem semiológica - ao lado de outros sentidos, especialmente aqueles de "paixão como fraqueza" e de "paixão como tóxico" - nessa noção platônica complexa e paradoxal de phármakon em sentido amplo - "esta não-substância farmacêutica" que se pode compreender como sendo as paixões igualmente em sentido amplo, em geral -, que remete, ao mesmo tempo, aos sentidos opostos de logos e de "filtro de esquecimento", de razão e de cegueira, de força e de fraqueza da vontade, de "remédio" e de "veneno", de "salvação" e de doença da alma etc., constituindo, no final das contas, a expressão, por assim dizer, da natureza paradoxal do homem e de suas paixões?

\title{
For a psychoanalytical semiology of passion in greek antiquity and its addictive and toxic meanings
}

\begin{abstract}
This is a literature review research. It aimed to produce a psychoanalytical semiology of passion in Greek Antiquity. the central hypothesis which compares"passion"to"addiction" and "toxin" was discussed. The following aspects were analyzed: 1st- The senses and the etymological origin of passion in Aristotle. We have highlighted passion here, in a broader sense, as "the fact of undergoing an action passively" and, in a restricted sense, as "the fact of suffering a painful action passively"; 2nd- The senses of passion in Plato. We have accentuated here, in a general sense, "passion-sensitive as the fact of undergoing an action passively" and, in a specific sense, "passion as blindness to reality", as a "sensorial illusion" and as "submission to an action coming from the outside world onto the body"; 3rd-Would the paradoxical sense of passions in Plato remain from the Renaissance, especially in Descartes and in Freud? and 4th- Would the Platonic "phármakon" be the semiological origin of the "toxic" and paradoxical senses of passions in general?
\end{abstract}

Keywords: Passion. Addiction. Toxin. Greek antiquity. Psychoanalytical semiology.

\section{Pour une sémiologie psychanalytique de la passion dans I'antiquité grecque et ses sens addictif et toxique}

Résumé: II s'agit d'une recherche de révision de la littérature. Son objectif a été faire la sémiologie psychanalytique de la passion dans l'Antiquité grecque. On a discuté l'hypothèse centrale qui compare la "passion" à I'"addiction" et au "toxique."On a analysé: ${ }^{\circ}$ - Les sens et l'origine étymologique de la passion chez Aristote. On y a souligné, au sens large, "passion comme fait de subir passivement une action" et, au sens restreint, comme "fait de souffrir passivement une action douloureuse ou nuisible"; $2^{\circ}$ - Les sens de la passion chez Platon. On y a mis en valeur le sens général de 
"passion-sensible comme fait de subir passivement une action" et les sens particuliers de"passion comme aveuglement face à la réalité",comme"illusion sensorielle"et comme "soumission à une action du monde extérieur sur le corps"; $3^{\circ}$ - Le sens paradoxal des passions chez Platon persisterait à partir de la Renaissance, notamment chez Descartes et chez Freud? et $4^{\circ}$ - Faut-il voir dans le "phármakon" de Platon l'origine sémiologique des sens"toxique" et paradoxal des passions en général?

Mots-clés: Passion. Addiction. Toxique. Antiquité grecque. Sémiologie psychanalytique.

\section{Para una semiología psicanalítica de la pasión en la antiguedad griega y sus sentidos adictivo y tóxico}

Resumen:Se trata de una pesquisa de revisión de la literatura.Su propósito fue hacer la semiología psicoanalítica de la pasión en la Antiguedad griega. Se discutió la hipótesis central que compara la "pasión" con la "adicción" y "tóxico". Se analizó: $1^{\circ}$ - Los sentidos y el origen etimológico de la pasión en Aristóteles. Se enfatizó aquí, en el sentido amplio, "pasión como hecho de sufrir pasivamente una acción", y, en el sentido restricto, como "hecho de sufrir una acción dolorosa o prejudicial"; $2^{\circ}$ - Los sentidos de la pasión en Platón. Se valorizó aquí, en sentido general, “pasión-sensible como hecho de sufrir pasivamente una acción" y, en sentido particular, "pasión como ceguera de la realidad", "como ilusión sensorial" y "como sumisión a una acción del mundo exterior sobre el cuerpo"; $3^{\circ}$ - ¿El sentido paradójico de las pasiones en Platón persistiría a partir del Renacimiento, especialmente en Descartes y en Freud?; $4^{\circ}$ - ¿Sería

el "phármakon" platónico el origen semiológico de los sentidos “tóxico”y paradójico de las pasiones en general?

Palabras-clave: Pasión. Adicción. Tóxico. Antigüedad griega. Semiología psicanalítica.

\section{Referências}

Aristote. (1991). Métaphysique (J. Tricot, trad., T. 1 - Livres A-Z). Paris: Librairie Philosophique J. Vrin.

Aristóteles. (2002). Metafísica (M. Perine, trad., Vol. 2). São Paulo: Loyola.

Bento, V. E. S. (1993). Tóxico, droga, toxicomania e adicção: uma introdução à etimologia segundo uma ótica psicanalítica. Jornal Brasileiro de Psiquiatria, 42(7), 373-380. 
Bento, V. E. S. (1994a). "Leonardo da Vinci e uma lembrança da sua infância": considerações sobre o narcisismo em Freud e sobre a paixão amorosa "tóxica" a partir de Freud. Temas: Teoria e Prática do Psiquiatra, 24(47), 94-113.

Bento, V.E. S. (1994b). Três ensaios sobre a teoria da sexualidade: considerações sobre o conceito de narcisismo em Freud (1905) e sobre a paixão amorosa "tóxica" a partir de Freud. Revista ABP-APAL, 16(4), 154-164.

Bento, V. E. S. (1995). O presidente Schreber, um caso de paranóia: considerações sobre o narcisismo em Freud (1911) e sobre a paixão amorosa "tóxica" a partir de Freud. Informação Psiquiátrica, 14(1), 27-35.

Bento, V. E. S. (1996). La passion amoureuse "toxique": une approche psychanalytique à partir de la sémiologie et du narcissisme chez Freud. Thèse de Doctorat (Psychopathologie Fondamentale et Psychanalyse), Université Paris 7, Paris, France.

Bento, V. E. S. (1998). O narcisismo em Freud e paixão "tóxica" a partir de Freud. Psicologia em Estudo, 3(2), 1-37.

Bento, V. E. S. (1999). Pour introduire une "sémiologie psychanalytique" de la notion de "toxicomanie" dans l'approche médicale. Interventions: Revue de l'ANIT Association Nationale des Intervenants en Toxicomanie, (68), 16-22.

Bento, V. E. S. (2003). O narcisismo em Freud e a paixão "tóxica" a partir de Freud. In M. Baptista, M. S. Cruz \& R. Matias (Orgs.), Drogas e pós-modernidade: prazer, sofrimento e tabu (Vol. 1, pp. 147-172). Rio de Janeiro: EdUERJ.

Bento, V. E. S. (2006a). Tóxico e adicção comparados a paixão e toxicomania: etimologia e psicanálise. Psicologia USP, 17(1), 181-206.

Bento, V. E. S. (2006b). Seria a semiologia de Saussure fundamento e justificativa para o método de pesquisa de revisão de literatura em psicanálise? Estudos de Psicologia, 23(4), 407-423.

Bento, V. E. S. (2007a). Totem e Tabu: uma "semiologia psicanalítica" em Freud? Estudos de Psicologia, 24(3), 397-406.

Bento, V. E. S. (2007b). Existiria uma "semiologia psicanalítica" em Lacan? Aletheia, (25), 177-190.

Bento, V. E. S. (2007c). Para uma semiologia psicanalítica das toxicomanias: adicções e paixões tóxicas no Freud pré-psicanalítico. Revista Mal-estar e Subjetividade, 7(1), 89-121.

Derrida, J. (1995). La pharmacie de Platon. In Platon \& J. Derrida, Phèdre suivi de La pharmacie de Platon (pp. 255-403). Paris: GF-Flammarion. (Trabalho original publicado em 1968)

Derrida, J. (1997). A farmácia de Platão (2a ed.). São Paulo: lluminuras. (Trabalho original publicado em 1968)

Descartes. (1994). Les passions de l'âme. Paris: Librairie Philosophique J. Vrin. (Trabalho original publicado em 1644)

Descartes, R. (1998). As paixões da alma. São Paulo: Martins Fontes. (Trabalho original publicado em 1644) 
Diderot, D., \&D'Alembert, J. L. (1967). Encyclopédie ou dictionnaire raisonné des sciences des arts et des métiers (Vol. 16). Stuttgart - Bad Cannstatt: Friedrich Frommann Verlag (Günther Holzboog). (Trabalho original publicado em 1765)

Diderot, D., \&D’Alembert, J. L. (1988). Encyclopédie ou dictionnaire raisonné des sciences des arts et des métiers (Vol. 1). Stuttgart - Bad Cannstatt: Friedrich Frommann Verlag (Günther Holzboog). (Trabalho original publicado em 1751)

Freud, S. (1974). Os instintos e suas vicissitudes. In S. Freud, Edição standard brasileira das obras psicológicas completas de Sigmund Freud (J. Salomão, trad., Vol. 14, pp. 127-162). Rio de Janeiro: Imago. (Trabalho original publicado em 1915)

Freud, S. (1992). Cinq psychanalyses (17e ed.). Paris: PUF. (Trabalho original publicado em 1954)

Green, A. (1988). As paixões e suas vicissitudes. In A. Green, Sobre a loucura pessoal (pp. 217-256). Rio de Janeiro: Imago.

Green, A. (1990). Passions et destins des passions. In A. Green, La folie privée. Psychanalyse des cas-limites (pp. 141-193). France: Gallimard.

Grimal, P. (1991). Dictionnaire de la mythologie grecque et romaine (11e ed.). Paris: PUF.

Grimal, P. (1993). Dicionário da mitologia grega e romana (2a ed.). Rio de Janeiro: Bertrand Brasil.

Lalande, A. (1993). Vocabulaire technique et critique de la philosophie (3e ed., Vols. 1-2). Paris: Quadrige. (Trabalho original publicado em 1926)

Lalande, A. (1996). Vocabulário técnico e crítico da filosofia (2a ed.). São Paulo: Martins Fontes. (Trabalho original publicado em 1926)

Laplanche, J., \& Pontalis, J.-B. (1990). Vocabulaire de la psychanalyse (10e ed.). Paris: PUF.

Laplanche, J., \& Pontalis, J.-B. (1998). Vocabulário da psicanálise (2a ed.). São Paulo: Martins Fontes.

Le Poulichet, S. (1987). Toxicomanies et psychanalyse. Les narcoses du désir. Paris: PUF.

Meyer, M. (1991). Le philosophe et les passions. Esquisse d'une histoire de la nature humaine. France: Librairie Générale Française.

Meyer, M. (1994). O filósofo e as paixões. Esboço de uma história da natureza humana. Porto, Portugal: Asa.

Organisation Mondiale de la Santé. (1974). Série de Rapports Techniques, no 551, Vingtième rapport. Genève.

Platão. (2003). Fédon (M. Ruas, trad.). São Paulo: Martin Claret.

Platão. (2004). A república (P. Nassetti, trad.). São Paulo: Martin Claret.

Platon. (1965). Phédon. In Platon, Apologie de Socrate, Criton, Phédon (É. Chambry, trad., pp. 81-180). Paris: GF-Flammarion; Garnier-Frères.

Platon. (1966). La republique (R. Baccou, trad.). Paris: GF-Flammarion.

Robert, P. (1992). Le Petit Robert 1: dictionnaire alphabétique et analogique de la langue française. Paris: Le Robert. 
Saussure, F. de. (1995a). Cours de linguistique générale (T. de Mauro, Édition critique). Paris: Payot \& Rivages. (Trabalho original publicado em 1916)

Saussure, F. de. (1995b). Curso de lingüística geral (A. Cheline, J. P. Paes, I. Blikstein, trads.). São Paulo: Cultrix. (Trabalho original publicado em 1916)

Valleur, M. (1991). Addiction. In Grand dictionnaire de la psychologie (p. 15). Paris: Larousse.

Victor Eduardo Silva Bento, Doutor em Psicopatologia Fundamental e Psicanálise pela Universidade Paris 7, Professor do Departamento de Psicometria do Instituto de Psicologia da Universidade Federal do Rio de Janeiro. Endereço eletrônico: vsilvabento@yahoo.com.br, victorbento@oi.com.br

Recebido em: 30/11/2007

Aceito em: 25/05/2008 